\title{
Integration of historic groundwater data into the Continent-scale Geochemistry Initiative
}

D. J. Gray, CSIRO Mineral Resources Flagship, PO Box 1130 Bentley, WA 6151, Australia

E-mail: david.gray@csiro.au

\section{SUPPLEMENTARY PAPERS}

Australian Journal of Earth Sciences (2016), 63, http://dx.doi.org/10.1080/08120099.2016.1218932

Copies of Supplementary Papers may be obtained from the Geological Society of Australia's website (www.gsa.org.au), the Australian Journal of Earth Sciences website (www.ajes.com.au) or from the National Library of Australia's Pandora archive (http://nla.gov.au/nla.arc-25194).

\section{SUPPLEMENTARY PAPERS}

Continental-scale hydrogeochemistry database 